\title{
Habitat Segregation Among Songbirds in Old-Growth Boreal Mixedwood Forest
}

\author{
ENID E. CUMMING
}

1542 Empress Ave., Saskatoon, Saskatchewan S7K 3G3 Canada

Cumming, Enid E. 2004. Habitat segregation among songbirds in old-growth boreal mixedwood forest. Canadian FieldNaturalist 118(1): 45-55.

The foraging behaviour of ten species of insectivorous songbirds - Boreal Chickadee (Poecille hudsonicus), Golden-crowned Kinglet (Regulus satrapa), Ruby-crowned Kinglet (R. calendula), Blue-headed Vireo (Vireo solitarius), Tennessee (Vermivora peregrina), Blackburnian (Dendroica fusca), Magnolia (D. magnolia), Yellow-rumped [Myrtle] (D. coronata), Black-throated Green (D. virens), and Bay-breasted (D. castanea) warblers - was observed in the boreal mixedwood forest of Prince Albert National Park in central Saskatchewan. Birds segregated their habitat use by preferentially foraging in different tree species, and through preferential use of different foraging locations (height and position) within trees.

White Spruce (Picea glauca) was used more than expected by Yellow-rumped Warblers, and Golden-crowned and Ruby-crowned kinglets. Tennessee and Magnolia warblers used White Birch (Betula papyrifera), more than expected and Boreal Chickadees and Blue-headed Vireos used Balsam Fir (Abies balsamea) more than expected. Boreal Chickadees, Ruby-crowned Kinglets, and Tennessee, Blackburnian and Yellow-rumped warblers all used the bottom part of trees less than expected, while Blueheaded Vireos foraged near the top of trees less than expected. Large inner branches were avoided by Tennessee, Blackburnian and Yellow-rumped warblers, while Bay-breasted Warblers and Blue-headed Vireos avoided small outer twigs. In conifers, Blackburnian Warblers foraged significantly higher in the trees than all other species except Black-throated Green and Baybreasted warblers. Blackburnian Warblers also foraged significantly higher than Blue-headed Vireos and Magnolia Warblers in deciduous trees.

Key Words: Songbirds, behaviour, foraging, boreal forest, old-growth, Prince Albert National Park, Saskatchewan.

Behavioural interactions and niche partitioning in songbirds have received much attention in the literature (MacArthur 1958; Sabo 1980; Maurer and Whitmore 1981). For many boreal songbirds, however, much on their basic biology remains poorly understood (Sodhi and Paszkowski 1995). Many of the detailed behavioral descriptions have come from studies conducted in the New England States (Rabenold 1978; Robinson and Holmes 1982; Hunt and Flaspohler 1998). This is likely an incomplete description for some birds, as several of the species discussed have their breeding ranges almost entirely restricted to the Canadian boreal forest (Ficken et al. 1996; Rimmer and McFarland 1998). Studies on the southern fringes of the boreal forest, in Maine or Minnesota, are not adequate on their own to understand boreal ecology as many of the plant and animal species are not the same as further north (Rowe 1972; Acton et al. 1998). Even for wide-ranging species, there is evidence that birds do not behave the same way and do not use the same kind of habitat in all parts of their range (Noon et al. 1980; Collins 1983; Robichaud and Villard 1999).

Recent studies in the boreal forest have focused on habitat associations, and habitat requirements of songbirds (Schieck et al. 1995; Kirk et al. 1996). This information is urgently needed in light of increased pressure from large-scale forestry in this region (Cummings et al. 1994). There is mounting evidence to show that mature and old boreal mixedwood forest support an entirely different suite of species not found in younger age classes (Stelfox 1995; Cumming and Diamond 2002). These older age classes of forest are currently under a harvesting intensity that is disproportionate to their abundance in the landscape (Cummings et al. 1994; Weyerhaeuser 1998*).

The goal of this project was to investigate details of within-stand habitat segregation among boreal songbirds, focusing on the foliage-gleaning songbird guild of old ( $>120$ years) boreal mixedwood forest. This type and age of forest was chosen as it was biologically the most diverse and structurally the most heterogeneous habitat in the region (Erskine 1977; Johnson et al. 1995; Robichaud and Villard 1999). In addition, mature to old (80+ years), mixedwood forest will become increasingly rare at the landscape level if current land use practices (i.e., logging, oil and gas exploration and agriculture) continue at their present rate (Cummings et al. 1994; Hobson et al. 2002; Schneider et al. 2002*).

\section{Study Area}

This study was carried out in the boreal, mixedwood forest of Saskatchewan (Kabzems et al. 1986; Acton et al. 1998), in Prince Albert National Park (53 $35^{\prime} \mathrm{N}$, $106^{\circ} 00^{\prime} \mathrm{W}$ ) during 1990 and 1991 (see Bayne and Hobson 1997 for description). Three sites were chosen in forest stands that were $>40$ ha in area and $>120$ years old. Sites were as similar in topography and vegetative cover as field conditions allowed. Stands were aged by forest inventory maps, and by taking core samples from six of the largest trees on each site. Each study 
site was surrounded by continuous forest of similar type, but younger age. None of the study sites had been subjected to forest harvesting, and wildfire was the driving force behind forest succession in this area (Weir et al. 2000).

The study sites were structurally very heterogeneous, with many tree-fall gaps and many standing dead trees. These canopy gaps allowed for regeneration, which resulted in a wide range of tree sizes and ages. Dominant tree species were White Spruce, Picea glauca, Balsam Fir, Abies balsamea, and Trembling Aspen, Populus tremuloides, with scattered White Birch, Betula papyrifera. Average canopy height was 21 metres with a maximum height of 38 metres (Cumming 1995). White Spruce was the only species that reached heights of over 30 metres, with some specimens also having diameters in excess of one metre. Understory trees $(<12$ metres), were mainly Balsam Fir, while the main shrubby species were Balsam Fir, White Birch saplings, and Alder, Alnus sp. Shrub distribution was patchy, with dense patches occurring in tree-fall gaps, and scattered shrubs in the rest of the study area. The most abundant ground cover species were various mosses, Bunchberry (Cornus canadensis), Wild Sarsasparilla (Aralia nudicaulis), Ostrich Fern (Matteuccia struthiopteris) and several horse-tail species (Equisetum spp.).

\section{Methods}

Observations on bird behaviour took place from late May to early August in 1990 and 1991, and birds were observed between 04:00 (dawn) and 21:00 (dusk). Upon locating a focal bird, continuous observations were made using binoculars until the bird was lost from sight (Altman 1974; Martin and Batson 1986). To avoid possible biases, observations that lasted less than five seconds or longer than two minutes were not used in the analysis. Bird species, behaviour, tree species and bird position in the tree were recorded. Bird height was estimated to within three metres. Linear regression analysis (Zar 1996) was used to ensure that estimates accurately reflected clinometermeasured heights (Cumming 1995).

In addition to behavioural observation, unlimited distance point counts (Bibby et al. 1982) were conducted twice during the breeding season (June), in order to estimate relative abundances of the various bird species. The average number of individuals per point count for each bird species was obtained by taking the maximum number recorded for that species and dividing by the number of point counts. Data from the three sites were pooled and used as a relative index of abundance for the study as a whole. For more details on bird species abundances see Cumming and Diamond (2002).

Following the method of MacArthur (1958), conifers were divided into 15 zones; 5 vertical and 3 horizontal, to determine in which part of the tree birds were foraging (Figure 1). Vertical zones divided the tree into fifths, with zone 1 at the top and zone 5 at the bottom. Horizontal zones corresponded to the outer part of the branch with new growth, fresh needles and small twigs (zone T), the middle layer of older needles and larger branches (zone M), and the inner part of the branch, largely devoid of needles with large diameter branches (zone B). A similar system was used for deciduous trees except they were divided into three vertical zones due to their more globular shape (Figure 2).

Although many birds exhibit male-female foraging differences (Holmes 1986), data for both sexes were pooled since the focus of the study was on interspecific differences in habitat use and because some species in the study were not sexually dimorphic. Bird foraging behaviour (tree zone use), did not differ significantly between the two species of conifer or between the two species of deciduous trees. Therefore, data for each bird species was pooled based on either coniferous or deciduous trees (Cumming 1995).

Vegetation in the study areas was measured using a modified James and Shugart (1970) method. Ten 0.04 ha circles ( $22 \mathrm{~m}$ diameter) were established in each study area, one centered on each of five point count stations and one at 50 metres in a random direction from that point. Within each circle, species, height in meters and diameter at breast height (dbh) in $\mathrm{cm}$ for all trees larger than $7 \mathrm{~cm}$ dbh were recorded. Percent basal area for each tree species was calculated using dbh values. Basal area more accurately reflected tree availability to birds than numbers of trees, due to heterogeneity in tree size.

To check for possible visibility biases in the various tree species, simultaneous confidence intervals (Chisquared with Bonferroni confidence intervals) were constructed by pooling the number of seconds of observation for all bird species (Byers et al. 1984). Simultaneous confidence intervals were also used to assess whether birds preferred or avoided certain tree species. Chi-squared test with Yates correction (Zar 1996) were used post priori to determine if birds had a preferred foraging zone within trees. Foraging diversity was analyzed using the Shannon Index (Shannon and Weaver 1949). To assess niche overlap between species, the proportion of observations each bird species spent in each of the 15 possible tree zones ( 9 zones in deciduous trees) was compared between each species pair using Morisita's Index of overlap (see Diamond 1983). With this index, potential niche overlap can vary from 1 (complete overlap) to 0 (no overlap). Foraging height data were analyzed using a 1way Anova (Proc GLM; SAS Institute 1988), and the results subjected to a Tukey's HSD pair-wise comparison test (with $\mathrm{P}=0.05$ ).

\section{Results}

\section{Tree Species Preference}

By basal area, White Spruce, Balsam Fir, Trembling Aspen and White Birch comprised 46\%, 30\%, 20\%, and $4 \%$, respectively, of the available arboreal habitat. 

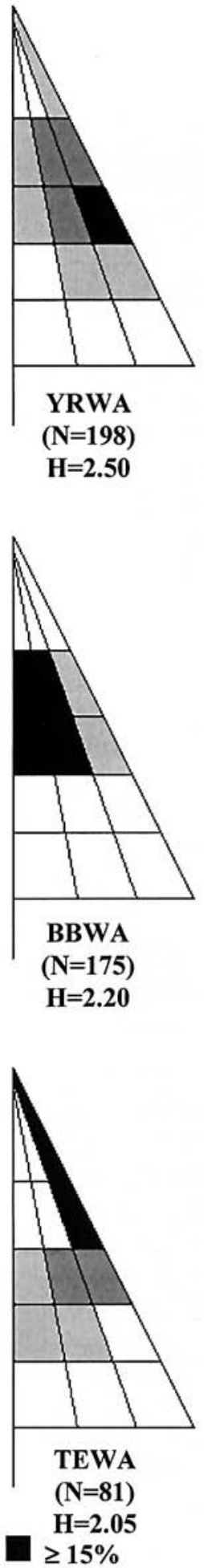
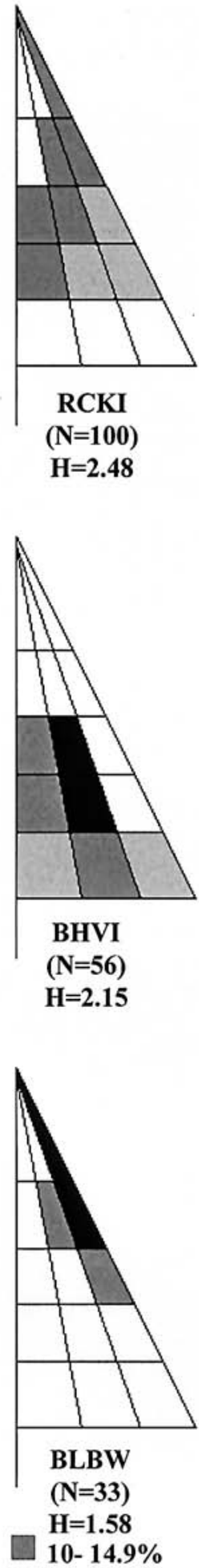

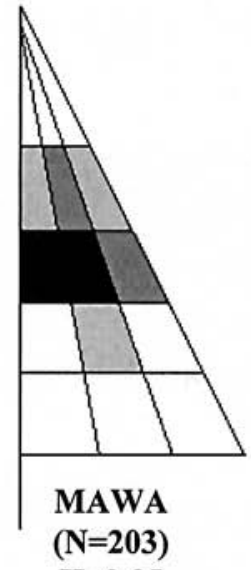

$\mathrm{H}=\mathbf{2 . 3 5}$
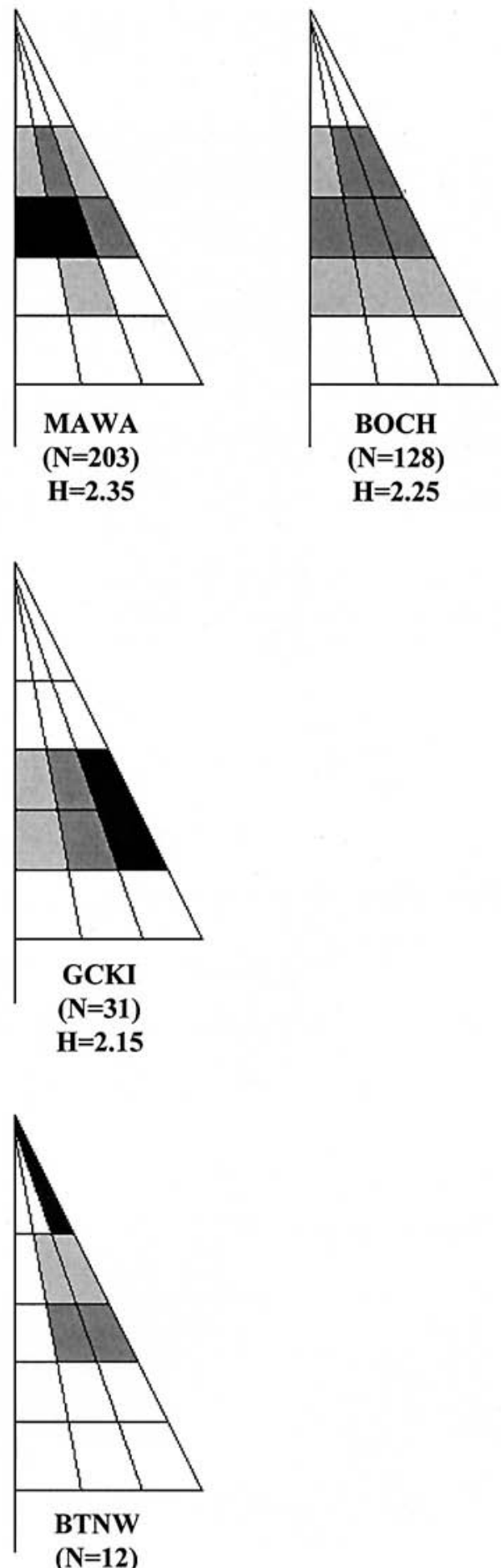

$(\mathrm{N}=12)$

$\mathrm{H}=1.56$

5- $9.9 \%$

\section{$0-4.9 \%$}

FIGURE 1. Songbird use of zones in coniferous trees. Shadings indicate frequency of observations within a zone (see legend). $\mathrm{N}=$ number of observations, $\mathrm{H}=$ Shannon diversity index. See Table 4 for species abbreviations. 
White Spruce was used more than expected by Yellow-rumped (Myrtle) Warbler, (Dendroica coronata), Golden-crowned (Regulus satrapa) and Rubycrowned ( $R$. calendula) kinglets and in proportion to its availability by all other species (Table 1). Balsam Fir was used more than expected by Boreal Chickadees (Poecile hudsonicus) and Blue-headed Vireos (Vireo solitarius) but less than expected by Tennessee Warblers (Vermivora peregrina). White Birch was used more than expected by Tennessee and Magnolia (Dendroica magnolia) warblers, while Trembling Aspen was used less than expected by Boreal Chickadees, Golden-crowned and Ruby-crowned kinglets, Blueheaded Vireos, Yellow-rumped and Magnolia warblers (Table 1). Bay-breasted Warblers (Dendroica castanea) used all tree species in proportion to their availability; however, they did exhibit a tendency to prefer White Spruce and avoid White Birch that was approaching significance. Blackburnian (D. fusca) and Black-throated Green (D. virens) warblers were not tested due to insufficient sample size (Brennan and Morrison 1990).

\section{Point counts}

All ten species were found in all three study sites, except Black-throated Green Warbler, which only occurred in one of the three study sites. Average bird abundance per point count from most to least abundant was; Magnolia Warbler (1.2), Yellow-rumped Warbler (0.8), Bay-breasted and Tennessee warblers (0.7), Blackburnian Warbler and Ruby-crowned Kinglet (0.4), Blue-headed Vireo (0.3), Boreal Chickadee and Golden-crowned Kinglet (0.2) and Black-throated Green Warbler (0.1).

\section{Foraging Zones}

In coniferous trees the most diversely foraging species (in order) were Yellow-rumped Warblers, Rubycrowned Kinglets, Magnolia Warblers, and Boreal Chickadees (Figure 1). These species were observed in most tree zones and had the highest diversity indices (Shannon and Weaver 1949). The least diversely foraging species were Black-throated Green Warblers, Blackburnian Warblers and Blue-headed Vireos (Figure 1).
In the vertical zones, Ruby-crowned Kinglets, and Tennessee and Yellow-rumped warblers used the bottom of the tree, less than expected, while Boreal Chickadees and Golden-crowned Kinglets used the top and bottom less than expected (Table 2). Blackburnian and Bay-breasted warblers used the bottom two zones less than expected, while Blue-headed Vireos used the top two zones less than expected (Table 2). For the horizontal zones Bay-breasted Warblers and Blue-headed Vireos both used small twigs on the ends of branches (zone T) less than expected, while Tennessee and Blackburnian warblers used small twigs (zone T) more than expected (Table 2). Yellowrumped Warblers use large inner branches (zone B) less than expected, while Boreal Chickadees, Goldencrowned and Ruby-crowned Kinglets and Magnolia Warblers showed no significant difference in their use of inner and outer branches. Black-throated Green Warblers were not tested due to insufficient sample size (Brennan and Morrison 1990). In deciduous trees, only six of the ten species had a large enough sample size to test foraging zone use (Figure 2). In deciduous trees, Blackburnian Warblers used the top of the trees more than expected. Yellow-rumped, Magnolia and Blackburnian warblers used zone B less than expected, and Tennessee Warblers used zone T more than expected (Table 2).

\section{Niche Overlap}

In conifers, niche overlap varied from $0 \%$ between Blue-headed Vireos and Blackburnian Warblers to 95\% between Yellow-rumped Warblers and both Magnolia Warblers and Boreal Chickadees The four most diversely foraging species, Boreal Chickadees, Ruby-crowned Kinglets, and Yellow-rumped and Magnolia warblers, all overlapped each other by $>80 \%$. In deciduous trees, the most foraging overlap was between Yellow-rumped and Blackburnian warblers and between Magnolia and Tennessee warblers; both species pairs overlapped by $88 \%$ (Table 3 ). The least amount of overlap in deciduous trees (40\%), was between Black-throated Green and Bay-breasted warblers.

TABLE 1. Bird use of different tree species compared to the tree's availability ( $\chi^{2}$ test with Bonferroni confidence intervals, $\mathrm{DF}=3$ for all species).

\begin{tabular}{lllrc}
\hline \hline & & & & \\
Bird Species & \multicolumn{2}{c}{ Use } & \multicolumn{1}{c}{$\chi^{2}$} & $\mathrm{P}$ \\
\hline Boreal Chickadee & Balsam Fir & Trembling Aspen & 43.3 & $* * *$ \\
Golden-crowned Kinglet & White Spruce & Trembling Aspen & 10.1 & $*$ \\
Ruby-crowned Kinglet & White Spruce & Trembling Aspen & 5.9 & $*$ \\
Blue-headed Vireo & Balsam Fir & Trembling Aspen & 6.3 & $*$ \\
Tennessee Warbler & White Birch & Balsam Fir & 50.7 & $* * *$ \\
Magnolia Warbler & White Birch & Trembling Aspen & 10.9 & $*$ \\
Yellow-rumped Warbler & White Spruce & Trembling Aspen & 21.2 & $* *$ \\
Bay-breasted Warbler & - & - & 5.0 & n.s. \\
\hline \hline
\end{tabular}

Significance: $*<0.05, * *<0.01, * * *<0.001$ 

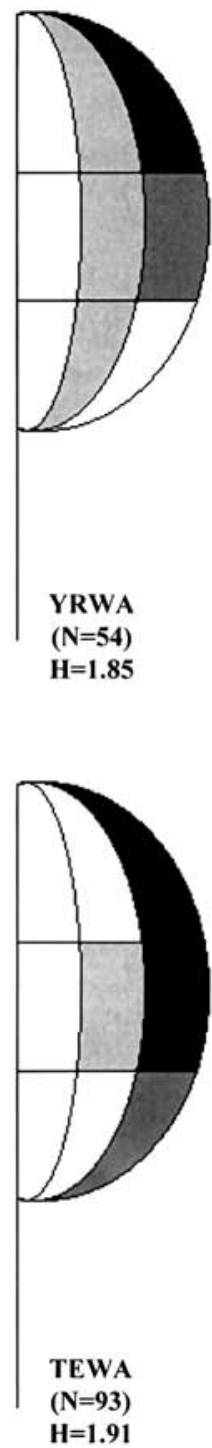
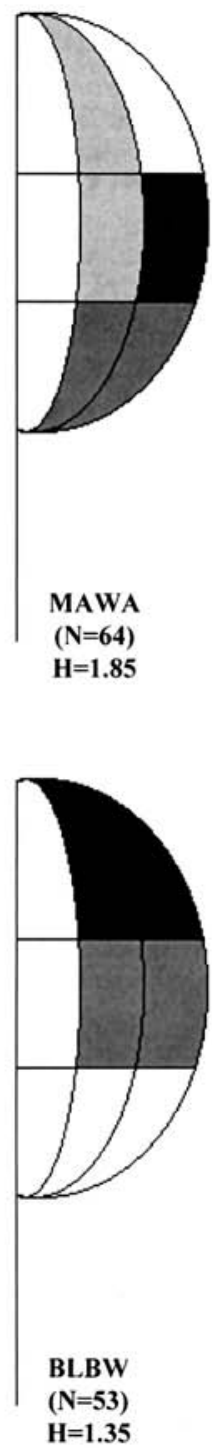
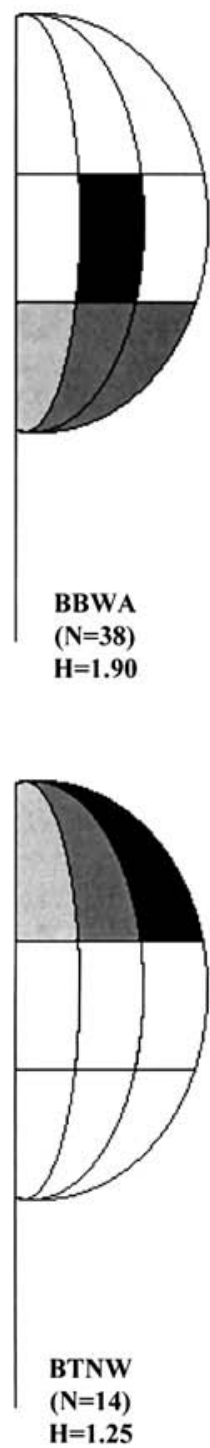

FIGURE 2. Songbird use of zones in deciduous trees. Shadings indicate frequency of observations within a zone (see legend). $\mathrm{N}=$ number of observations, $\mathrm{H}=$ Shannon diversity index. See Table 4 for species abbreviations.

\section{Foraging Height}

In coniferous trees, the average foraging height of Blackburnian Warblers was significantly higher than all other species except Black-throated Green and Baybreasted warblers (Table 4). Black-throated Green and Bay-breasted warblers both foraged significantly higher than Magnolia Warblers and Blue-headed Vireos. Foraging heights of all other species were not significantly different (Table 4). In deciduous trees, the average foraging height of Blackburnian Warblers was significantly higher than that of Blue-headed Vireos and Magnolia Warblers but not significantly different from other species.

\section{Canopy vs. Subcanopy Use}

Blackburnian, Black-throated Green, and Tennessee warblers were seen in canopy level trees ( $>12$ metres) in two-thirds or more of all observations (Table 5). At the other extreme, two-thirds of the observations on 
TABLE 2. Bird use of tree zones where zone use was significantly more or less than expected ( $\chi^{2}$ test with Yates's correction; $\mathrm{DF}=1$ for all species).

\begin{tabular}{|c|c|c|c|c|c|c|c|c|}
\hline \multirow[t]{2}{*}{ Species } & \multicolumn{4}{|c|}{ Horizontal Zones } & \multicolumn{4}{|c|}{ Vertical Zones } \\
\hline & $\mathrm{T}, \mathrm{M}, \mathrm{B}$ & Use & $\chi^{2}$ & $\mathrm{P}$ & 1 to 5 & Use & $\chi^{2}$ & $\mathrm{P}$ \\
\hline \multicolumn{9}{|l|}{ In Coniferous Trees } \\
\hline Boreal Chickadee & n.s. & & & & 1,5 & $<$ & 20.4 & $* * *$ \\
\hline Golden-crowned Kinglet & n.s. & & & & 1,5 & $<$ & 14.5 & $* * *$ \\
\hline Ruby-crowned Kinglet & n.s. & & & & 5 & $<$ & 16.5 & $* * *$ \\
\hline Blue-headed Vireo & $\mathrm{T}$ & $<$ & 20.9 & $* * *$ & 1,2 & $<$ & 11.1 & $* * *$ \\
\hline Tennessee Warbler & $\mathrm{T}$ & $>$ & 14.9 & $* * *$ & 5 & $<$ & 11.2 & $* * *$ \\
\hline Blackburnian Warbler & $\mathrm{T}$ & $>$ & 18.5 & $* * *$ & 4,5 & $<$ & 7.4 & $* *$ \\
\hline Magnolia Warbler & n.s. & & & & 3 & $>$ & 13.7 & $* * *$ \\
\hline Yellow-rumped Warbler & $\mathrm{B}$ & $<$ & 14.6 & $* * *$ & 5 & $<$ & 10.1 & $* *$ \\
\hline Bay-breasted Warbler & $\mathrm{T}$ & $<$ & 10.5 & $* *$ & 4,5 & $<$ & 7.5 & $* *$ \\
\hline \multicolumn{9}{|l|}{ In Deciduous Trees } \\
\hline Tennessee Warbler & $\mathrm{T}$ & $>$ & 30.3 & $* * *$ & n.s. & & & \\
\hline Blackburnian Warbler & $\mathrm{B}$ & $<$ & 24.9 & $* * *$ & 1 & $>$ & 6.6 & $*$ \\
\hline Magnolia Warbler & B & $<$ & 15.5 & $* * *$ & n.s. & & & \\
\hline Yellow-rumped Warbler & $\mathrm{B}$ & $<$ & 23.7 & $* * *$ & n.s. & & & \\
\hline
\end{tabular}

Significance: $*<0.05, * *<0.01, * * *<0.001 ; \mathrm{T}=$ outer part of branch with new growth, fresh needles and small twigs; $\mathrm{M}=$ middle layer of older needles and larger branches; B = inner part of branch, largely devoid of needles with large diameter branches; 1 to 5 : vertical zones, $1=$ top, $5=$ bottom.

TABLE 3. Average (mean $\pm \mathrm{SD}$ ) foraging height (metres) in coniferous and deciduous trees. Species marked with * foraged significantly higher than other species (1-way Anova with Tukey's HSD test, $\mathrm{P}=0.05$ ).

\begin{tabular}{lcc}
\hline \hline Bird Species & Coniferous & Deciduous \\
\hline Boreal Chickadee & $6.1 \pm 3.4$ & $9.1 \pm 5.2$ \\
Golden-crowned Kinglet & $7.0 \pm 2.9$ & $9.2 \pm 3.1$ \\
Ruby-crowned Kinglet & $7.3 \pm 4.7$ & $9.5 \pm 4.7$ \\
Blue-headed Vireo & $6.1 \pm 2.0$ & $6.3 \pm 3.8$ \\
Tennessee Warbler & $8.6 \pm 3.3$ & $9.5 \pm 5.7$ \\
Blackburnian Warbler & $15.7 \pm 7.8 *$ & $15.7 \pm 3.9 *$ \\
Magnolia Warbler & $5.8 \pm 2.2$ & $6.9 \pm 5.0$ \\
Black-throated Green Warbler & $12.7 \pm 7.8^{*}$ & $11.4 \pm 3.8$ \\
Yellow-rumped Warbler & $7.0 \pm 4.2$ & $11.2 \pm 3.8$ \\
Bay-breasted Warbler & $10.3 \pm 4.8^{*}$ & $11.8 \pm 3.1$ \\
\hline \hline
\end{tabular}

Coniferous: Blackburnian Warbler foraged significantly higher than all but Black-throated Green Warbler and Bay-breasted Warbler. Black-throated Green Warbler and Bay-breasted Warbler foraged significantly higher than Blue-headed Vireo and Magnolia Warbler.

Deciduous: Blackburnian Warbler foraged significantly higher than Blue-headed Vireo and Magnolia Warbler.

Magnolia Warblers and Boreal Chickadees were in subcanopy trees (Table 5). Blue-headed Vireos and Ruby-crowned Kinglets were approximately equal in their use of canopy and subcanopy trees, while Goldencrowned Kinglets and Yellow-rumped and Bay-breasted warblers tended to be observed slightly more often in canopy level trees (Table 5). Yellow-rumped Warblers were observed in canopy level trees significantly more than Magnolia Warblers $(\mathrm{Z}=5.2, \mathrm{P}<0.001)$ and Boreal Chickadees $(\mathrm{Z}=3.4, \mathrm{P}<0.001)$.

\section{Discussion}

\section{Tree Species Preference}

The four main tree species in the study area (White Spruce, Balsam Fir, Trembling Aspen, and White Birch), were not equally abundant, nor equally large (Cumming 1995). If abundance alone had been used as the criteria for tree availability for foraging then Balsam Fir would have appeared to comprise a larger proportion of available habitat than it actually did.

Patches of old, White Spruce-dominated forest are relatively rare in Saskatchewan (Kabzems et al. 1986; Acton et al. 1998); therefore, it was expected that birds which prefer White Spruce would selectively occupy this habitat. The data appear to support this, as all species in the study used White Spruce either in proportion to, or greater than, its abundance. Yellowrumped Warblers and Golden-crowned and Rubycrowned kinglets all used White Spruce more than expected. Boreal Chickadees and Blue-headed Vireos used White Spruce in proportion to its abundance and used Balsam Fir more than expected. All five species used Trembling Aspen less than expected (Table 1). This is similar to their behaviour elsewhere, as other researchers have found these five species to be conifer specialists (Keast and Saunders 1991; Ingold and Wallace 1994; Ingold and Galati 1997).

Trembling Aspen was the least favored tree; it was used less than expected by half the bird species in the study. Previous research has suggested differences in insect abundance may exist between aspen and other tree species (Ives and Wong 1988). Holmes and Robinson (1981) suggested structural characteristics of aspen trees and their leaves may impede foraging by insectivorous birds. However, Greenburg (1979) felt that Yellow-rumped and Bay-breasted warblers were phys- 


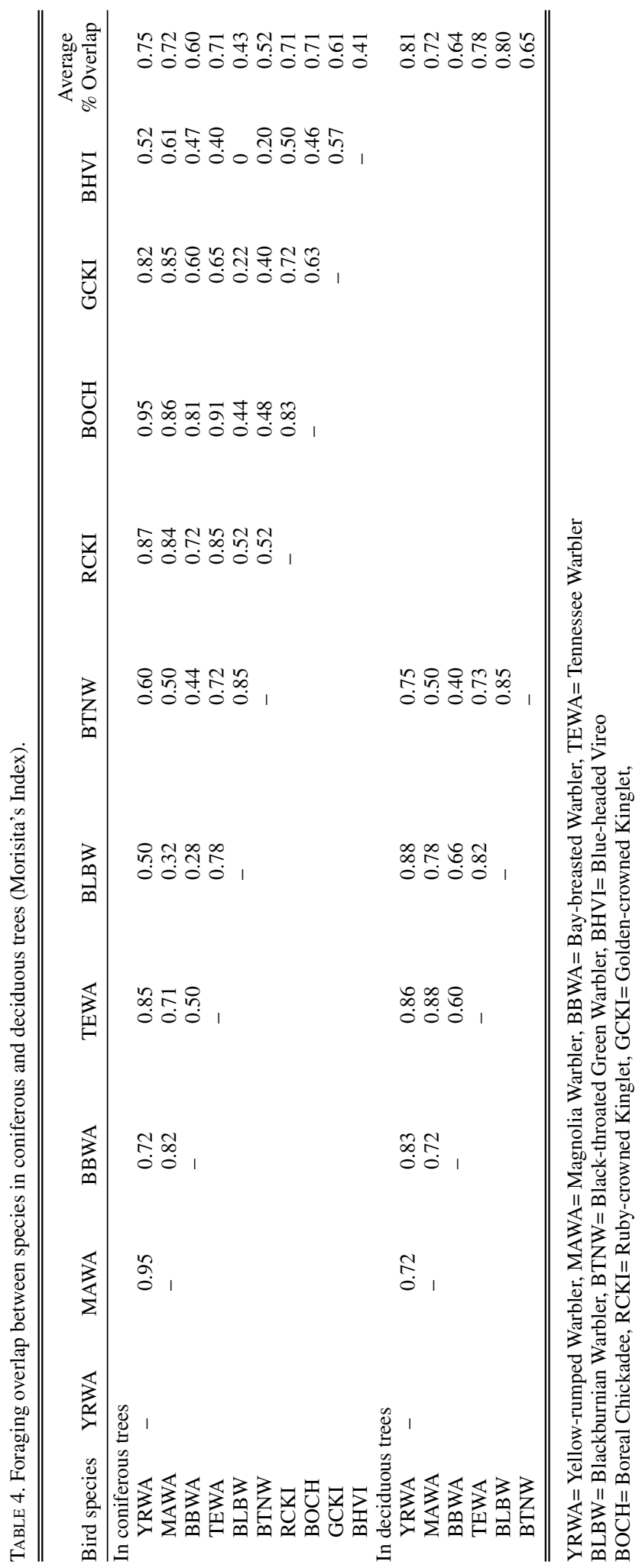


TABLE 5. Bird use of canopy versus subcanopy trees, from most to least canopy using species.

\begin{tabular}{lcc}
\hline \hline & \multicolumn{2}{c}{ Number of Observations } \\
Bird Species & Canopy & Subcanopy \\
\hline Blackburnian Warbler & 62 & 7 \\
Black-throated Green Warbler & 17 & 5 \\
Tennessee Warbler & 80 & 41 \\
Yellow-rumped Warbler & 94 & 63 \\
Bay-breasted Warbler & 73 & 55 \\
Golden-crowned Kinglet & 16 & 12 \\
Ruby-crowned Kinglet & 27 & 25 \\
Blue-headed Vireo & 24 & 25 \\
Boreal Chickadee & 29 & 50 \\
Magnolia Warbler & 60 & 126 \\
\hline \hline
\end{tabular}

ically adapted to foraging in conifers and both their body size and foraging habits impeded foraging in deciduous trees.

Tennessee and Magnolia warblers both used White Birch more than expected. Morse (1989) felt that many songbirds preferred various Betula species for mechanical reasons; they had smaller leaves than other trees (especially Fagus, Acer and Populus) and were easier for gleaning songbirds to reach. Other studies have found various species of birch have higher densities of lepidopteran larvae than other trees (Holmes and Robinson 1981; Holmes and Shultz 1986). An insufficient sample size prevented testing of Blackthroated Green Warbler's tree species preference. It is notable, however, that $50 \%$ of the foraging observations on this species were in White Birch, even though these trees represented only $4 \%$ of the available habitat. Other researchers (Holmes and Robinson 1981; Robichaud and Villard 1999) have also found that Blackthroated Green Warblers are partial to birch and use it greater than expected by chance alone.

Tennessee Warblers used Balsam Fir less than expected, while Blackburnian and Black-throated Green warblers were never observed in this tree. Although Blackburnian and Black-throated Green warbler use of this tree could not be tested, the fact that Balsam Fir comprised $30 \%$ of the available trees suggests that both birds were avoiding it. Blackburnian and Black-throated Green warblers were consistently observed high in the canopy, so Balsam Fir with an average height of $11 \pm 5.6$ metres may have been too short to attract these species (Cumming 1995). Branch structure may also have played a role in some birds' avoidance of fir. Differences in branch shape have been attributed to several bird species' preference of Red Spruce (Picea rubens) over White Spruce (Morse 1989; Parrish 1995). Balsam Fir branches were less ridged than those of White Spruce (personal observation). Birds which preferentially foraged on thin outer twigs appeared to have more difficulty foraging on the tips of Balsam Fir branches than they did in White
Spruce (personal observation). This was particularly noticeable in Tennessee Warblers because this species focused most of its foraging activities on the outer twigs and new growth in both coniferous and deciduous trees. In contrast, birds which foraged in many tree zones (Yellow-rumped, Magnolia, and Bay-breasted warblers) appeared to be less affected by branch structure and they used Balsam Fir in proportion to its availability.

\section{Foraging}

Boreal Chickadees were the only permanent residents in the study and one of the few passerines that are resident in the boreal forest (Ficken et al. 1996). It is considered an advantage for birds to be flexible in their foraging habits when they live in an unpredictable environment, like the boreal forest (Hunt and Flaspohler 1998). Boreal Chickadees were diverse foragers, using most tree zones and overlapping more than $80 \%$ with Ruby-crowned Kinglets and Yellowrumped, Magnolia, Bay-breasted and Tennessee warblers. Other studies found Boreal Chickadees had an average foraging height of five metres, and used all parts of the tree branch (Sabo and Holmes 1983; Ficken et al. 1996). Similarly, I found Boreal Chickadees foraged at an average height of six metres and showed no significant difference in their use of inner and outer branches. They did however, use the top and bottom of trees less than expected. Boreal Chickadees may have avoided the tops of trees because this zone was heavily used by several other species. Boreal Chickadees have been shown elsewhere to shift their foraging activity lower in the trees due to competition from Black-capped Chickadees (Vassallo and Rice 1981). Boreal Chickadees also tended to forage in small subcanopy trees more than any other species except Magnolia Warblers.

Ruby and Golden-Crowned kinglets were similar in their behaviour; however, Ruby-Crowned Kinglets were usually higher in the trees and were more diverse foragers. Rabenold (1978) found that where Rubycrowned Kinglets and Golden-crowned Kinglets occurred together, Ruby-crowned Kinglets were more diverse in their foraging activity and occurred higher in the canopy than Golden-crowned Kinglets. Franzreb (1984) felt this was due to social dominance of Ruby-crowned over Golden-crowned kinglets. No interspecific social interactions were observed in this study; however, Ruby-crowned Kinglets were twice as abundant as Golden-crowned Kinglets and may have influenced the behaviour of the latter through numerical dominance.

Large inner and middle branches were favoured by both Blue-headed Vireos and Bay-breasted Warblers; this was an area of the trees that was seldom used by other species. There was only moderate foraging overlap $(47 \%)$ between Blue-headed Vireos and Baybreasted Warblers, as they foraged at significantly different heights. Foraging on large inner and middle 
branches is similar to the behaviour these two species have displayed elsewhere (Williams 1996; James 1998).

Both Blackburnian and Black-throated Green warblers foraged high in the trees (significantly higher than most other species), and had larger foraging overlap with each other $(85 \%)$ than they did with any other species. These warblers appeared to be specialized in a tree-top niche, and have been identified in many studies as feeding, singing, and nesting high in coniferous trees (Morse 1993, 1994). Indeed, Morse (1994) found that Blackburnian Warblers were unlikely to be found in forest without at least some conifers over 18 metres tall. Unlike MacArthur (1958) and Morse (1989), I found no evidence that Black-throated Green Warblers were socially dominant over any other species in the study area. This may have been because Black-throated Green Warblers were the least abundant bird in the study and only occurred in one of three study sites.

Similar to their behaviour elsewhere, Tennessee Warblers were observed at a variety of heights in all tree species, but foraged mainly on the terminal foliage (Rimmer and McFarland 1998). Foraging on the tips of the branches and using many different trees may help Tennessee Warblers (a Vermivora warbler) fit into a community (spruce-fir forest) that already has several coexisting species of Dendroica warblers (Morse 1989). Tennessee Warblers also used White Birch more than any other species except Magnolia and Black-throated Green warblers. Greenburg (1979) felt that small warblers were better able to forage on deciduous foliage than larger warblers for the physical reasons. Tennessee, Magnolia and Black-throated Green warblers were smaller than most species, except for the two kinglets, and Boreal Chickadees, which were conifer specialists. Therefore, they may have been using a food resource that the larger Yellow-rumped and Bay-breasted warblers would have trouble exploiting.

I found Magnolia Warblers used subcanopy trees more than any other species and had the lowest average foraging height of all species observed. This was similar to Hall (1994), who found Magnolia Warblers used mainly young conifers and were seldom found at any great height. Magnolia Warblers displayed no significant difference in their use of inner, middle and outer parts of branches. This was likely because they most often foraged young trees; there was far less difference in branch structure between inner and outer parts of branches in young trees than there was in large old trees (personal observations).

Yellow-rumped Warbler showed the greatest diversity of foraging habits. They used almost every tree zone in both coniferous and deciduous trees. Yellowrumped Warblers have been noted elsewhere as being generalists and this flexibility is thought to help them withstand adverse conditions better than their congeners (Rabenold 1978; Hunt and Flaspohler 1998). Unlike their behaviour elsewhere (MacArthur 1958;
Morse 1989), Yellow-rumped Warblers did not use mainly the bottom and inner branches. Yellow-rumped Warblers occurred most often in the middle and outer branches at mid to upper heights in both conifers and deciduous trees, the same zone frequented by Blackthroated Green Warblers in other studies (MacArthur 1958; Morse 1989). Morse (1971) and Howe (1979) felt that the presence or absence of Black-throated Green Warblers caused shifts in Yellow-rumped Warbler foraging activity. I observed no social interactions between Yellow-rumped and Black-throated Green warblers, and as Yellow-rumped Warblers were eight times more abundant, there was likely little interspecific competition between these two species. Indeed, Yellow-rumped Warblers experienced the most overlap, and likely the most interspecific competition, from Magnolia Warblers, Boreal Chickadees, and Rubycrowned Kinglets (Table 4 and Figure 1).

\section{Niche Overlap}

Northern regions, such as the boreal forest, are thought to have such large pulses of seasonally available food that for songbirds food saturation occurs (Rabenold 1983; Wiens 1989). This seasonal pulse of food, combined with a high number of neo-tropical migrants, allows greater niche overlap between songbirds than occurs in other habitats (Rabenold 1978, 1983; Wiens 1989). Rabenold (1978) found that sprucefir forests in particular had a high number of songbirds which were "...broadly overlapping congeners". Although the present study and Rabenold's were not directly comparable, many of the species were the same between the two studies and results from this study support his theory of generalist stacking. Species with the most generalized foraging behaviour had the highest amount of niche overlap, while those with more specialized foraging behaviour had little niche overlap.

\section{Canopy vs. Subcanopy}

Availabilty of canopy versus subcanopy trees was not measured; therefore, I could not test whether birds were significantly selecting one over the other. At the two extremes, however, it was apparent that Blackburnian Warblers were using very tall trees almost exclusively, while Magnolia Warblers were using mostly young regenerating trees.

I tested Yellow-rumped Warblers' use of canopy and subcanopy trees against Magnolia Warblers' and Boreal Chickadees' because they had a $95 \%$ foraging overlap (in conifers) with both species (83\% with Magnolia Warbler in deciduous trees). A Z-test (in results) found Yellow-rumped Warblers used tall (canopy) trees significantly more than the other two species. I felt this was a significant difference between these species, as they used the available habitat in a similar way and they did not forage at significantly different heights. Magnolia and Yellow-rumped warblers were also the two most abundant species in study.

Previous research has shown old-growth boreal mixedwood forest such as those studied here to harbor 
unique communities not seen in pre-rotation age forest (Erskine 1977; Kirk et al. 1996: Cumming and Diamond 2002). This diverse songbird community appears to be caused by an interaction between a structurally diverse habitat and a mixture of generalized and specilized foraging behaviours of the bird species involved. Although this study did not examine multiple age classes of forest, it would appear that the community dynamics seen here may be fairly unique due to canopy gap dynamics that tend to be associated with old-growth forest (Hunter 1990). This type and age-class of forest has not received the attention it deserves from either environmental impact studies or long-term management plans for the boreal forest. The scientific community needs to pay greater attention to the contribution old-growth boreal mixedwood forest makes to biodiversity on both a regional and national scale.

\section{Acknowledgments}

This study was carried out in partial fulfillment of the requirements for a M.Sc. degree at the University of Saskatchewan. Parks Canada allowed field work to be carried out in Prince Albert National Park. Funding was provided by the Canadian Wildlife Service, Prince Albert National Park, Nature Saskatchewan, and the Saskatchewan Wildlife Habitat Development Fund. Office, laboratory and computer space was provided by the Canadian Wildlife Service in Saskatoon. A special thank you to my husband S. L. Van Wilgenburg for help with tables and figures and to my supervisor A. W. Diamond for advice and support during thesis research and preparation. This manuscript was improved by helpful comments from S. L. Van Wilgenburg, K. A. Hobson, and A. J. Erskine.

\section{Documents cited (marked $*$ in text)}

Schneider, R. R., J. B. Stelfox, S. Boutin, and S. Wasel. 2002. Managing the cumulative impacts of land uses in the Western Canadian Sedimentary Basin: a modelling approach. Conservation Ecology 7: 8. [online] URL: http:// www.consecol.org/vol7/iss $1 /$ art8

Weyerhaeuser Canada. 1998. Twenty-year forest management plan \& environmental impact statement. Weyerhaeuser Canada and Saskatchewan Environment and Resource Management. Prince Albert, Saskatchewan.

\section{Literature Cited}

Acton, D. F., G. A. Padbury, and C. T. Stushnoff. 1998. The Ecoregions of Saskatchewan. Canadian Plains Research Centre/Saskatchewan Environment and Resource Management. Hignell, Winnipeg.

Altman, J. 1974. Observational study of behaviour: sampling methods. Behaviour 48: 227-267.

Bibby, C. J., N. D. Burgess, and D. A. Hill. 1982. Bird census techniques. Academic Press, London, United Kingdom.

Bayne, E. M., and K. A. Hobson. 1997. Comparing the effects of landscape fragmentation by forestry and agriculture on predation of artificial nests. Conservation Biology 11: 1-13.

Brennan, L. A., and M. L. Morrison. 1990. Influence of sample size on interpretations of foraging patterns by chestnut-backed chickadees. In Studies in avian biology. Number 13: 187-192. Edited by M. L. Morrison, C. J. Ralph, J. Verner, and J. R. Jehl Jr. Publication of the Cooper Ornithological Society.

Byers, C. R., R. K. Steinhorst, and P. R. Krausman. 1984. Clarification of a technique for analysis of utilizationavailability data. Journal of Wildlife Management 48: 1050-1053.

Collins, S. A. 1983. Geographic variation in habitat structure of the Black-throated Green Warbler. Auk 96: 382389.

Cumming, E. E. 1995. Songbird habitat use in Saskatchewan old-growth, boreal mixedwood forest. M.Sc. thesis, University of Saskatchewan, Saskatoon, Canada.

Cumming, E. E., and A. W. Diamond. 2002. Songbird community composition versus forest rotation age in Saskatchewan boreal mixedwood forest. Canadian Field-Naturalist 116: 69-75.

Cummings, S. E., P. J. Burton, S. Prahacs, and M. R. Garland. 1994. Potential conflicts between timber supply and habitat protection in the boreal mixedwood of Alberta, Canada: a simulation study. Forest Ecology and Management 68: 281-302.

Diamond, A. W. 1983. Feeding overlap in some tropical and temperate seabird communities. Studies in Avian biology number 8: 24-46.

Erskine, A. J. 1977. Birds in Boreal Canada. Canadian Wildlife Service Report Series 4: 1-73.

Ficken, M. S., M. A. McLearen, and J. P. Hailman. 1996. Boreal Chickadee (Parus hudsonicus). In The Birds of North America, number 254. Edited by A. Poole and F. Gill. The Academy of Natural Sciences, Philadelphia, Pennsylvania, and The American Ornithologists' Union, Washington, D. C.

Franzreb, K. E. 1984. Foraging habits of ruby-crowned and golden-crowned kinglets in an Arizona montane forest. Condor 86: 139-145.

Greenburg, R. 1979. Body size breeding habitat and winter exploitation systems in Dendroica. Auk 96: 757-766.

Hall, G. A. 1994. Magnolia warbler (Dendroica magnolia). The Birds of North America, Number 136. Edited by A. Poole and F. Gill. The Academy of Natural Sciences, Philadelphia, Pennsylvania. The American Ornithologists' Union, Washington, D. C.

Hobson, K. A., E. M. Bayne, and S. L. Van Wilgenburg. 2002. Large-scale conversion of forest to agriculture in the boreal plains of Saskatchewan. Conservation Biology 16: $1-13$.

Holmes, R. T. 1986. Foraging patterns of forest birds: male and female differences. Wilson Bulletin 987: 196-213.

Holmes, R. T., and S. K. Robinson. 1981. Tree species preferences of foraging insectivorous birds in a northern hardwood forest. Oecologia 48: 31-35.

Holmes, R. T., and J. C. Shultz. 1986. Food availability for forest birds: effects of prey distribution and abundance on bird foraging. Canadian Journal of Zoology 66: 720-728.

Howe, R. W. 1979. Distribution and behaviour of birds on small islands in northern Minnesota. Journal of Biogeography 6: 379-390.

Hunt, P. D., and D. J. Flaspohler. 1998. Yellow-rumped Warbler (Dendroica coronata). The Birds of North America. Number 376. Edited by A. Poole and F. Gill. The Academy of Natural Sciences, Philadelphia, Pennsylvania, and The American Ornithologists' Union, Washington, D. C. 
Hunter, M. I. 1990. Wildlife, forests and forestry. Prentice Hall, Englewood Cliffs, New Jersey.

Ingold, J. L., and R. Galati. 1997. Golden-crowned Kinglet (Regulus satrapa). The Birds of North America. Number 301. Edited by A. Poole and F. Gill. The Academy of Natural Sciences, Philadelphia, Pennsylvania, and The American Ornithologists' Union, Washington, D. C.

Ingold, J. L., and G. E. Wallace. 1994. Ruby-crowned Kinglet (Regulus calandula). The Birds of North America. Number 119. Edited by A. Poole and F. Gill. The Academy of Natural Sciences, Philadelphia, Pennsylvania, and The American Ornithologists' Union, Washington, D. C.

Ives, W. G. H., and H. R. Wong. 1988. Tree and shrub insects of the prairie provinces. Canadian Forestry Service information report NOR-X-292.

James F. C., and H. H. Shugart. 1970. A quantitative method of habitat description. Audubon Field Notes 24: 727-737.

James, R. D. 1998. Blue-headed Vireo (Vireo solitarius). The Birds of North America. Number 379. Edited by A. Poole and F. Gill. The Academy of Natural Sciences, Philadelphia, Pennsylvania and the American Ornithologists' Union, Washington, D. C.

Johnson, E. A., K. Miyanishi, and J. M. H. Weir. 1995. Old-growth, disturbance and ecosystem management. Canadian Journal of Botany, 73: 918-926.

Kabzems, A., A. L. Kosowan, and W. C. Harris. 1986. Mixedwood section in an ecological perspective. Saskatchewan Parks and Renewable Resources. Technical Bulletin 8. Second edition.

Keast, A., and S. Saunders. 1991. Ecomorphology of North American Ruby-crowned (Regulus calandula) and Goldencrowned (Regulus satrapa) kinglets. Auk. 108: 880-888.

Kirk, D. A., A. W. Diamond, K. A. Hobson, and A. R. Smith. 1996. Breeding bird communities of western and northern Canadian boreal forest: relationship to forest type. Canadian Journal of Zoology 74: 1749-1770.

MacArthur, R. H. 1958. Population ecology of some warblers of northeastern coniferous forest. Ecology 39: 599619.

Martin, P., and P. Batson. 1986. Measuring behaviour: an introductory guide. Cambridge University Press, Cambridge.

Maurer, B. A., and R. C. Whitmore. 1981. Foraging of five bird species in two forests with different vegetational structure. Wilson Bulletin 94: 478-490.

Morse, D. H. 1971. The foraging of warblers isolated on small islands. Ecology 52: 216-228.

Morse, D. H. 1989. American warblers. Harvard University Press. Cambridge, Massachusetts.

Morse, D. H. 1993. Black-throated Green Warbler (Dendroica virens). The birds of North America. Number 55. Edited by A. Poole and F. Gill. The Academy of Natural Sciences, Philadelphia, Pennsylvania, and the American Ornithologists' Union, Washington, D. C.

Morse, D. H. 1994. Blackburnian Warbler (Dendroica fusca). The birds of North America. Number 102. Edited by A. Poole and F. Gill. The Academy of Natural Sciences, Philadelphia, Pennsylvania and the American Ornithologists' Union, Washington, D. C.

Noon, B. R., D. K. Dawson, D. B. Inkly, C. S. Robbins, and S. H. Anderson. 1980. Consistency in habitat preference of forest bird species. Transcripts from the North American Wildlife \& Natural Resources Conference 45: 226-244.

Parrish, J. D. 1995. Effects of needle architecture on warbler habitat selection in a coastal spruce forest. Ecology
76: $1813-1820$.

Rabenold, K. N. 1978. Foraging strategies, diversity and seasonality in bird communities of Appalachian spruce-fir forest. Ecological Monographs 48: 397-424.

Rabenold, K. N. 1983. Latitudinal gradients in avian species diversity and the role of long distance migrants. Pages 247274 in Current Ornithology Volume 10. Plenum Press. New York.

Rimmer, C. C., and K. P. McFarland. 1998. Tennessee Warbler (Vermivora perigrina). The Birds of North America. Number 350. Edited by A. Poole and F. Gill. The Academy of Natural Sciences, Philadelphia, Pennsylvania, and The American Ornithologists' Union, Washington, D. C.

Robichaud, I., and M. A. Villard. 1999. Do Black-throated Green Warblers prefer conifers? Condor 101: 262-271.

Robinson, S. K., and R. T. Holmes. 1982. Foraging behaviour of forest birds: the relationships among search tactics, diet and habitat structure. Ecology 63: 1919-1931.

Rowe, J. S. 1972. Forest regions of Canada. Department of Environment Canada Forest Service Publication Number 1300.

Sabo, S. R. 1980. Niche and habitat relations in subalpine bird communities of the White Mountains of New Hampshire. Ecological Monographs 50: 241-259.

Sabo, S. R., and R. T. Holmes. 1983. Foraging niches and the structure of forest bird communities in contrasting montane habitats. Condor 85: 121-138.

SAS Institute Inc. 1988. SAS/STAT User's Guide, 6.03 edition. SAS Institute Inc., Cary, North Carolina.

Schieck, J., M. Nietfeld, and J. B. Stelfox. 1995. Difference in bird species richness and abundance among three successional stages of aspen-dominated boreal forests. Canadian Journal of Zoology 73: 1417-1431.

Shannon, C. E., and W. Weaver. 1949. The mathematical theory of communication. University of Illinois Press. Ubana, Illinois.

Sodhi, N. J., and C. A. Paszkowski. 1995. Research on wood warblers in Canadian boreal forest. Journal of Field Ornithology 66: 260-266.

Stelfox, J. B. Editor. 1995. Relationships between stand age, stand structure and biodiversity in the aspen mixedwood forests in Alberta. Alberta Environmental Centre, Vegreville, Alberta.

Vassallo, M. I., and J. C. Rice. 1981. Differential passerine density and diversity between Newfoundland and offshore Gull Island. Wilson Bulletin 93: 340-349.

Weir, J. M. H., E. A. Johnson, and K. Miyanishi. 2000. Fire frequency and the spatial age mosaic of the mixedwood boreal forest in western Canada. Ecological Applications 10: 1162-1177.

Wiens, J. A. 1989. The ecology of bird communities. Volume 1: Foundations and Patterns. Cambridge University Press, Cambridge.

Williams, J. M. C. I. 1996. Bay-breasted warbler (Dendroica castanea). The Birds of North America. Number 206. Edited by A. Poole and F. Gill. The Academy of Natural Sciences, Philadelphia, Pennsylvania, and The American Ornithologists' Union, Washington, D. C.

Zar, J. H. 1996. Biostatistical analysis. Third edition. Prentice-Hall. Englewood Cliffs, New Jersey.

Received 10 March 2001

Accepted 20 May 2004 